\title{
The Screening, Characterization and Identification of Chitinolytic Actinomycetes Streptomyces sp. ANU5a.
}

\section{Piyush Kumar Tiwari}

Centyle Biotech Private Limited

Shubhjeet Mandal ( $\nabla$ shubhjeetm@gmail.com )

Centyle Biotech Private Limited https://orcid.org/0000-0002-8745-4237

Anchal Anchal

University of Delhi - South Campus

\section{Research Article}

Keywords: ANU5a, Actinomycetes, Biocontrol, Chitinase, 16S rDNA, Rhizobacteria, Enzyme activity

Posted Date: April 29th, 2021

DOI: https://doi.org/10.21203/rs.3.rs-473198/v1

License: (c) (i) This work is licensed under a Creative Commons Attribution 4.0 International License. Read Full License 


\section{Abstract}

Streptomyces sp. ANU5a is a potential plant growth-promoting Rhizobacteria and a highly effective biocontrol agent. It produces Chitinases in broth media containing Chitin. Earlier reports on the chitinase production revealed the key importance of casein hydrolysate and yeast extract as additional sources of carbon and nitrogen to increase the yield. 16S rRNA-based method was used to identification of a Chitinolytic Actinomycete a Streptomyces sp. ANU5a was completed from Mangrove soil samples. Ammonium sulphate precipitation method was used for partial purification of Chitinases. The Chitinases have optimum activity at a temperature of $50-55^{\circ} \mathrm{C}$ and $\mathrm{pH} 5-6$. Three protein bands of $20 \mathrm{kDa}, 67 \mathrm{kDa}$, and $240 \mathrm{kDa}$ are resolved by Native-PAGE of Ammonium Sulphate fractions; the smallest band of $20 \mathrm{kDa}$ belongs to Chitinase. Enzyme activity for chitinase was recorded by zymogram analysis. Streptomyces $s p$. ANU5a was found to have notable antifungal activity on culture plates. We correlate the antimicrobial activity of Streptomycetes $s p$. ANU5a with Chitinase activity and other PGPR traits.

\section{Key Points}

- $16 \mathrm{~S}$ based identification of Chitinolytic actinomycetes Streptomyces sp. ANU5a.

- Antimicrobial activity of Streptomycetes sp. ANU5a with Chitinase activity and other PGPR traits.

- Charecterization of Streptomycetes sp. ANU5a by various physiochemical method/assays.

\section{Introduction}

Streptomycetes $s p$. in the phyla Actinomycetes are broadly identified for the commercial level production of secondary metabolites and enzymes in variety of applications viz. medicine, agriculture and environment sectors. Streptomyces spp. produces several chitinolytic enzymes to decompose chitins, some examples of these bacterial species includes $S$. antibioticus, S. griseus, S. plicatus, S. lividans, S. aureofaciens and S. halstedii. Chitinase producing actinomycetes are getting attenention due to their plant promotion and biocontrol property. They are soil borne microorganism and this could be another reason for their exploited use in bio-production and agriculture. Chitinolytic enzymes have different applications in research fungal protoplast preparation that degrades cell wall of fungi or ophthalmic preparations in human health care. Chitinase containing hydrolytic enzyme cocktails are using in paper pulp industry for high quality product formulation. In addition to immense application of chitinase and chitinolytic enzymes in medical and bio processing industry, they have major role in agricultural applications like PGPR, Bio-control and transgenic plant development against phytopathogens. Fungi represents a major group of phytopathogens which are aggressive in nature and typically treated chemically using fungicides. Exhaustive usage of such fungicides results as a major contributor to environmental pollution, increased pathogenicity in plants and increased resistance in species of veterinary importance such as arthropods and helminths (Sanborn et al. 2002).

Additionally, these chemicals are proven for serious health hazards to humans and deleterious effect on helpful insects in agriculture. The important consortium of bacteria is also disturbed in the affected ecological niche. This is one of the reasons to facilitate the use of biological control in future generation agriculture strategies. To follow up advancements in this field of research, chitinolytic bacteria or chitinases are proposed to be used as an alternative to chemical treatment for increased yield. These kind of approaches in agriculture can have direct impact on environment and human health.

Over the past few years streptomyces and certain bacillus were investigated as good plant growth promoters. Bacteria that directly or indirectly increases the plant growth via different mechanisms are known as plant growth promoting bacteria (PGPB). A recent inclination towards these bacteria in production is promising to increase the crop yield. Other inputs to dramatically increase the crop yield over the past 50 years primarily includes agricultural fertilizers enriched in nitrogen and phosphorus. There are limitations in the sustainability of crops cultivated through conventional methods.

At present, there are only few examples of commercially available chitinases from bacteria. Bacillus, Serratia, and Streptomyces spp. produces chitinolytic enzymes with limitations in optimal activity due to acidic pH (Kielak et al., 2013). As development of new and worth enzyme technology, researchers around the world are looking for ideal enzyme producers, for that point of view they are screening millions of isolates and cultures and another side few are trying to develop new strain via recombinant DNA 
technology or by mutagenesis. In few screening programs, researchers are trying to correlate lytic funtion of bacterial exolate with their hydrolytic enzyme activity. In doing so, many studies divulge that antifungal activity is associated with chitinases as well as antifungal metabolites like 2-furancarboxaldehyde (S. Y. Lee et al., 2012).

Advancement on biocontrol and plant growth promotion strategies will be beneficial for commercial and agricultural means. This particular area of research is needed for exploratory and sustainable development. Therefore, further investigation on this area will be a great achievement for the researchers in coming near future. In this study, we did optimisation in the culture conditions for better yield of chitinase, also the screening and characterisation of metabolites by the Streptomyces strains (Table 1).

\section{Materials And Methods}

\subsection{Materials}

Bushnell and Haas Medium (BHM), Luria-Bertani Broth, Actinomycetes Isolation Agar gelatin, casein hydrolysate, yeast extract, indole3-acetic acid and $\mathrm{N}$-acetylglucosamine were obtained from Hi-Media, India. All other solvents and chemicals used during the experiment were of analytical grade. The polymeric substrates $\alpha$-chitin (extracted from shrimp shells), $\beta$-chitin (extracted from squid pen) and chitin flakes (milled shrimp shell chitin) procured from Mahatani Chitosan Pvt. Ltd. (Veraval, India) were added to BHM as a substrate for enzyme production. Phytopathogenic fungi namely, Aspergillus flavus MTCC 16404, Fusarium oxysporum NCIM1072 and Magnaporthae oryzae were obtained from Microbial Type Culture Collection (MTCC), Institute of Microbial Technology, Chandigarh and National Collection of Industrial Microorganisms (NCIM), National Chemical Laboratory, Pune

\subsection{Preparation of Colloidal chitin}

Colloidal chitin was prepared as described by Aida et al. (2014) with minor modification. A known amount of dried chitin was suspended in concentrated hydrochloric acid and kept for overnight at $4^{\circ} \mathrm{C}$, followed by precipitation of dissolved chitin by chilled distilled water and centrifuged at 10,000 rpm for 20 minutes at room temperature. The pellet was washed repeatedly with distilled water until the $\mathrm{pH}$ of the chitin suspension was neutralized.

\subsection{Screening of chitinolytic actinobacteria}

Pre-obtained Actinobacterial cultures of mangrove soil sediment were screened for their chitinolytic activity. Cultures were inoculated on colloidal chitin $(0.1 \%, \mathrm{w} / \mathrm{v})$ containing agar plate, followed by cultivation at $30^{\circ} \mathrm{C}$ for $72 \mathrm{~h}$. Individual cultures with clear zone resulting from hydrolysis of chitin were selected for further screening and characterization. In order to get better visibility, plates were stained with Calcoflore White and observed under UV (Anil et al 2007). Clear zone against fluorescent background could be considered as positive chitinase producer.

\subsection{In vitro screening for plant growth promoting traits}

\subsubsection{Indole-3-acetic acid production}

Production of Indole-3-Acetic Acid (IAA) by actinobacterial isolates was investigated using Actinomycetes broth (Sodium caseinate, $\mathrm{K}_{2} \mathrm{HPO}_{4}, \mathrm{MgSO}_{4}, \mathrm{FeSO}_{4}$, L-Asparagine, ) supplemented with yeast extract (1g/L) and Tryptophan (1g/L). Loopful of actively growing culture was inoculated and incubated for $72 \mathrm{~h}$ at $30^{\circ} \mathrm{C}$ and $120 \mathrm{rpm}$ (Worsley et al., 2020). After $72 \mathrm{~h}$ of incubation, culture supernatant was assayed for IAA using Salkowaski's reagent ( $50 \mathrm{~mL}$ of $35 \%$ perchloric acid and $1 \mathrm{~mL}$ of $0.5 \mathrm{M}$ $\mathrm{FeCl}_{3}$ ) as per the method Brick et al (1991).

\subsubsection{Phosphate solubilization}

Phosphate solubilization by the actinobacterial isolates was checked using Pikovaskya's agar plate (Yeast extract $0.5 \mathrm{~g} / \mathrm{l}$, Dextrose $10 \mathrm{~g} / \mathrm{l}$, Tri-calcium phosphate $5 \mathrm{~g} / \mathrm{l}$, Ammonium sulphate $0.5 \mathrm{~g} / \mathrm{l}$,Potassium chloride $0.2 \mathrm{~g} / \mathrm{l}$, Mangnesium sulphate 0.1 $\mathrm{g} / \mathrm{l}$, Manganese sulphate $0.0001 \mathrm{~g} / \mathrm{l}$, Ferrous sulphate $0.0001 \mathrm{~g} / \mathrm{l}$, Agar $20 \mathrm{~g} / \mathrm{l})$. The cultures were spot inoculated on the 
Pikovaskya's Agar plate and incubated for 7 days at $30^{\circ} \mathrm{C}$. Positive phosphate solubilising bacteria was identified as a colony with clear halo.

\subsubsection{Siderophore production}

Production of siderophore by the actinobacterial isolates was determined using Chrome Azurol S (CAS) as per the method of Schwyn and Neiland (1991) with minor modifications. The Actinomycetes broth was deferrated before autoclaving using 8hydroxyquinoline $(0.1 \% \mathrm{w} / \mathrm{v})$ as a iron-chelating agent. Sterilized $10 \%(\mathrm{v} / \mathrm{v})$ CAS dye solution was added to the sterilized Actinomycetes medium and mixed properly before pouring into petridish. Actinobacterial isolates were spot inoculated onto these plates and incubated for $96 \mathrm{~h}$ at $30^{\circ} \mathrm{C}$. Siderophore production by bacterial isolates was indicated by an orange halo around the colony.

\subsubsection{Screening for organic solvent tolerance}

The actinobacterial cultures were spot inoculated on BHM plates using sterile tooth picks, after which each plate was flooded with $10 \mathrm{~mL}$ of different solvents [iso-octane (log Pow=4.5), n-heptane (log Pow=4.39), n-hexane (log Pow=3.86), cyclohexane (log Pow=3.2), xylene (log Pow=3.1), toluene (log Pow=2.64), benzene (log Pow=2.13), chloroform (log Pow=2.0)] and incubated at $30^{\circ} \mathrm{C}$ in an air-tight canister inorder to prevent the evaporation of the solvent from the plates. After incubation, the plates were observed for growth.

\subsubsection{Antifungal activity}

A co-culture technique (Trivedi et al 2008) was used to test the ability of actinobacterial isolates to inhibit the growth of several phytopathogenic fungi (Aspergillus flavus MTCC 16404, Fusarium oxysporum NCIM 1072 and Magnaporthae oryzae). The cultures were spot inoculated on one side of oat meal agar plate and incubated at $30^{\circ} \mathrm{C}$ for $48 \mathrm{~h}$ after which each fungal strain was inoculated next to the bacterial culture and incubated at $30^{\circ} \mathrm{C}$ (Hrdý et al., 2020). The plates were incubated up to 5 days for monitoring antifungal activity.

\subsection{Extracellular enzyme production}

\subsubsection{Amylase}

Bacterial isolates were inoculated on $\mathrm{BHM}$ containing $(1 \%, \mathrm{w} / \mathrm{v})$ starch and incubated at $30^{\circ} \mathrm{C}$ for $48 \mathrm{~h}$. After incubation, plates were flooded with iodine solution. Positive culture exhibited clear zone around the colony against the blue black background due to hydrolysis of starch.

\subsubsection{Cellulase}

Culture were inoculated on on BHM containing $(1 \%, w / v) ~ C M C$ and incubated at $30^{\circ} \mathrm{C}$ for $72 \mathrm{~h}$. After incubation, plates were flooded with $(0.1 \%, \mathrm{w} / \mathrm{v})$ Congo red for $1 \mathrm{~h}$ at room temperature followed by destaining with $1 \mathrm{M} \mathrm{NaCl}$ till suitable contrast is obtained. The clear zone around the culture indicated production of cellulase enzyme.

\subsubsection{Protease}

In order to screen for protease producers, BHM amended with $(1 \%, \mathrm{w} / \mathrm{v})$ gelatine agar plates were used. Cultures were spot inoculated and incubated for $72 \mathrm{~h}$ at $30^{\circ} \mathrm{C}$. Then agar plates were flooded with $10 \mathrm{~mL}$ of Frazeir's reagent $\left(15 \% \mathrm{HgCl}_{2}\right.$ in $\left.2 \mathrm{~N} \mathrm{HCl}\right)$. Clear zone around colony were marked as protease producers.

\subsubsection{Lipase}

Actinobacterial isolates producing lipase were screened using BHM agar plates amended with Tributyrine (1\% v/v). Bacterial cultures were spot inoculated and incubated at $30^{\circ} \mathrm{C}$ for $120 \mathrm{~h}$. Zone of clearance around the colony indicated production of lipase enzyme. 


\subsubsection{Maintenance of isolates}

The potential cultures were sub-cultured and maintained on Actinomycetes isolation agar slants and preserved in refrigerator at $4^{\circ} \mathrm{C}$.

\subsection{Identification of bacterial isolate}

\subsubsection{6s rRNA based molecular identification of ANU5a}

Genomic DNA was extracted from the selected isolates according to Ausubel et al. (1997). PCR was done using 16S rRNA universal primers 8F (5'-AGAGTTTGATCCTGGCTCAG-3') and 1492R (5'-GGTTACCTTGTTACGACTT-3') (MWG Biotech Pvt. Ltd., Bangalore, India) using 20-25 ng template DNA and $30 \mu \mathrm{l}$ of each PCR reaction for 35 cycles. The thermocycler was set up for each PCR cycle of initial denaturation at $94^{\circ} \mathrm{C}$ for 5 mins followed by denaturation at $94^{\circ} \mathrm{C}$ for 2 mins, annealing at $55^{\circ} \mathrm{C}$ for 1 min, extension at $72^{\circ} \mathrm{C}$ for 15 mins (BioRad PCR cycler, USA).Agarose Gel electrophoresis was done for PCR products using $1.2 \%$ w/v agarose gel in TAE buffer (1X). 1 kb DNA ladder (Bangalore Genei, Bangalore, India) was used to compare the resolution of bands. EtBr stained gel was visualized in Gel Documentation system (Alpha-Inotech, USA). Agarose gel purified PCR products were used in sequencing by automated DNA analyzer 3730 using ABIPRISMs BigDye ${ }^{\text {TM }}$ cycle sequencing kit (Applied Biosystems, FosterCity, CA). The sequencing results produced approximately $1400 \mathrm{bp}$ of sequences, sequence data was analysed using NCBI servers and submitted to NCBI Genbank.

\subsection{Inoculum preparation}

The inoculum was prepared by method of Butterworth (1984) with minor modification. Chitinolytic actinobacterium ANU5a was inoculated on Actinomycetes isolation agar plate and incubated at $30^{\circ} \mathrm{C}$ for $48 \mathrm{~h}$ after which the spores were harvested using Tween $20(0.1 \%, w / v)$ amended $(20 \%, w / v)$ glycerol and stored at $-20^{\circ} \mathrm{C}$. Henceforth, this seed culture will be used as inoculum.

\subsection{Profile of chitinase production by ANU5a}

The $250 \mathrm{ml}$ Erlenmeyer flasks containing $100 \mathrm{~mL}$ of BHM amended with $(0.5 \%, \mathrm{w} / \mathrm{v})$ chitin flakes was inoculated with activated seed culture of ANU5a and incubated on orbital shaker $(120 \mathrm{rpm})$ at $30^{\circ} \mathrm{C}$. The aliquots of $2 \mathrm{~mL}$ were withdrawn after $24,48,96$, 120 and $144 \mathrm{~h}$ of inoculation and monitored for chitinase activity.

\subsection{Medium optimization for chitinase production by ANU5a}

The optimization of medium components for chitinase production by isolate ANU5a was done following one factor at a time approach. Here, the components were varied one at a time with the remaining factors held constant. The chitinase production by isolate ANU5a in BHM medium containing different chitinous source at $(1 \%, w / v)$ as a sole carbon source viz. $a$-chitin, $\beta$-chitin, colloidal chitin $(\alpha$ and $\beta)$. Similarly, 250ml Erlenmeyer flasks containing $100 \mathrm{ml}$ of $(1 \%, w / v)$ a-chitin in BHM with varying nitrogen sources were inoculated with ANU5a and incubated at $30^{\circ} \mathrm{C}$. The influence of temperature $\left(30^{\circ} \mathrm{C}\right.$ and $\left.37^{\circ} \mathrm{C}\right), \mathrm{pH}(5$ to 8$)$ on chitinase production by isolate ANU5a was also investigated.

\subsection{Analytical procedure:}

\subsubsection{Chitinase assay}

Chitinase assay was performed using modified colorimetric method for the estimation of $\mathrm{N}$ acetyl amino sugar as described by Schales (Schales and Schales 1945). One unit of chitinase activity was defined as the amount of enzyme required to liberate $1 \mathrm{ng}$ of $\mathrm{N}$-acetylglucosamine/mL.min under specified assay conditions.

\subsection{SEM analysis of chitin degradation by ANU5a}

The visualize the extent of polymer degradation, the degraded chitin flakes were were immersed in iso-amylacetate, dried using liquefied carbon dioxide and coated with a layer of sublimated osmium tetroxide using an osmium plasma-coater (Itoh et al., 
2013). The osmium plasma coated specimens were glued onto carbon-aluminium stub and viewed under Scanning Electron Microscope (JSM-6320F; JEOL Ltd., Tokyo, Japan). Scanning was performed using at $10 \mathrm{kV}$.

\subsection{Zymogram analysis}

Chitinase activity was detected in polyacrylamide gels containing chitin as described by Escott et al. (1998).

\section{Results}

\subsection{Identification and Screening of Chitinolytic bacteria}

Bacteria that produces chitinase have shown poor chitinolytic activity, sometimes requires additional hydrolytic enzyme or even microorganism to boost up their chitinolytic property (Anné et al., 2014). Studies on chitinase production by bacteria have described the role of actinomycetes in natural environments e.g. soil where it contributes to recycle nutrients (Gopalakrishnan, Pande, et al., 2011). They are therefore potential source of hydrolytic enzymes and thus antagonist to major phytopathogens (Jayamurthy et al., 2014). Therefore, this study aims at screening Actinomycetes as a potential source of chitinase enzyme.

Twenty-five actinobacterial cultures were checked for antagonistic activity against phytopathogenic fungus and among them ANU5a, ANU5b, CAI155a, CAl155b, CAl127, CAl140b, KAl27b and KAI90 were found to effectively inhibit fungal growth (Figure 2.1).

Among these eight antagonistic actinobacteria ANU5a broadly exhibited antifungal activity against all the phytopathogenic fungi tested. The difference in extent of inhibition from one organism to other could be attributed to the difference in efficiency and specificity of the antagonistic agent (enzyme/metabolite) produced by the culture (Table 2.1)

\subsection{In vitro plant growth promotion of actinobacterial isolates}

The preliminary screening results for PGP traits have been tabulated in Table 2.2. Almost all the isolate possesses one or the other PGP trait. IAA production was the best trait being observed in the test cultures. From the present investigation, $56 \%$ isolates generate IAA in the approximate amount of $19.75-55 \mu \mathrm{g} / \mathrm{mL}$. The ability of bacteria to produce IAA depends on the availability of precursor molecule i.e. L-tryptophan. Root exudates are one of the important natural source of tryptophan that probably accelerate the auxin biosynthesis in the rhizosphere soil (Khamna et al., 2009).

Production of siderophore was also detected by only $52 \%$ of isolates (Table 2.2). The isolates on CAS agar formed an orange halo around the colonies. Most of them exhibited high ability to produce siderophores. Usually, soil microbes produces siderophores that bind to $\mathrm{Fe}^{3+}$ ions in the iron deficient environment. These siderophores bind to the iron molecule and transport it back to the microbial cell and make it available for growth (W. Lee et al., 2012). These siderophores can also be used by plants to source iron as macronutrient. A possible mechanism to control the phytopathogens also includes competition for iron, inhibition of phytopathogens through hydroxymate-type siderophores by streptomyces in plant rhizosphere soil is a good example for stimulating competition for iron in plant growth development (Khamna et al., 2009). Siderophore may increase the availability of minerals to soil bacteria that results into biosynthesis of antimicrobial compounds.

Among 25 cultures, $32 \%$ isolates were found to solubilize precipitated phosphate after $196 \mathrm{~h}$ incubation (Figure 2.2). The bacteria could solubilize phosphorus either by organic acid and/or acid phosphatase production(Sharma et al., 2011). The action of organic acid synthesis by soil microbes is generally accepted for the mechanism involving mineral phosphate solubilization. Some of the examples of organic acids among phosphate solubilizers are glycolic, oxalic, lactic, fumaric, acetic, malonic, succinic acid (Sharma et al., 2011).

Therefore, among the above tested isolates, 3 isolates CAI 155a, CAI 155b, ANU 5b were showing maximum number of screened traits and ANU 5a exhibited almost all traits, which may promote plant growth directly or indirectly. Similar to our finding of multiple PGP activity, Streptomycetes have been reported to enhance plant growth (Khamna et al., 2009, Ahmad, Ahmad, \& Khan, 2008). While such reports from Indian subcontinent is very sparse. 


\subsection{Solvent tolerance on extracellular chitinase production}

In order to screen for solvent tolerance, these four selected cultures were monitored for growth and chitinase activity on solvents flooded plates. Table 2.3, shows the solvent tolerance and chitinase production by 3 selected bacterial isolates in presence of isooctane, n-Hexane, and iso-octane. Among these 3 isolates, ANU5a showed broad spectrum reponse toward solvent tolerance. However, growth of all isolates was inhibited Methanol, Acetone, Benzene, Toluene and Dichloromethane. Organic solvent tolerant chitinase in Streptomycetes is less reported than till date.

\subsection{Selection of chitinolytic strain for chitinase production}

The chitinolytic activity of the four selected isolates (CAI155a, CAI155b, ANU5a and ANU5b) were further confirmed by growing them in $100 \mathrm{~mL}$ BHM broth amended with $0.5 \%$ of a-chitin. Chitinase activity was measured by using Schales reagent. Figure 2.3 represents the chitinase activity of these 4 isolates.

Soil isolates ANU5a showed maximum chitinase activity as 0.032 Units $/ \mathrm{mL}$. Thus, ANU 5 a was selected for further investigation.

\subsection{SrDNA identification of ANU5a}

The sequencing results for ANU5a shares 99\% sequence identity with 16S rDNA of Streptomyces cavourensis. We have submitted the sequence to NCBI GenBank with accession number KR061434. The analyzed sequence was subsequently used to construct a phylogenic tree to compare ANU5a and its genetically close relatives (Figure 2.4).

\subsection{Influence of temperature and pH on ANU5a chitinase activity}

The chitinase enzyme assay was performed at different $\mathrm{pH}(5,6$ and 7$)$ and temperature $\left(30^{\circ} \mathrm{C}\right.$ and $\left.37^{\circ} \mathrm{C}\right)$ to determine the optimal $\mathrm{pH}$ and temperature for the chitinase activity. Streptomycetes sp. ANU5a chitinase exhibited optimal activity at $5.0 \mathrm{pH}$ and $50^{\circ} \mathrm{C}$ temperature, respectively (Figure $2.5 \mathrm{~A}, 2.5 \mathrm{~B}$ ).

\subsection{Profile of chitinase production by ANU5a}

The duration of incubation period offers the potential for the cost effective production of enzymes. Time course study was carried out for the chitinolyic Streptomycetessp. ANU5a. The production of extracellular chitinases was detected by withdrawing the sample from each production flask (with additional supplement A without additional supplement B) at time interval of $24 \mathrm{~h}$.

Chitinase activity in production medium without any additional source other than chitin and BHM showed maximum activity at $72 \mathrm{~h}$ of incubation and after which the activity declined. Whereas, the maximum activity for chitinase in production medium $\mathrm{B}$ supplemented with additional nutritional sources was detected to be at $120 \mathrm{~h}$ of incubation and after which the activity declined. Figure (2.6A) represents that Streptomycetes sp. ANU 5a secretes chitinase with maximum activity of $110 \mathrm{U} / \mathrm{mL}$ in production medium B, whereas Figure (2.6B) exhibited 34 Units $/ \mathrm{mL}$ in production medium A. This study indicates, additional nutritional sources are required for better enzyme production.

\subsection{Optimization of chitinase production}

Optimization of medium and production parameter for chitinase production by selecting the best nutritional and environmental condition is important to increase the chitinase yield (Saadoun et al., 2009). The traditional method of "optimizing one factor at a time" technique was used in this study. This method is determined by varying one factor while keeping the other factor at a constant level.

The aim of this investigation was to optimize the chitinase production medium for Streptomyces sp. ANU 5a. The cultural characters were optimized by amending with different concentration of chitin, various carbon and nitrogen sources, optimum pH, temperature and amino acid source supplementation were studied.

\subsection{Effect of different chitin substrate on chitinase production by Streptomyces ANU5a}


A study pertaining to the physiological requirement of any culture enables one to manipulate conditions so as to maximize product formation. There are difference in the performance of various Actinomycetes on the sources of carbon and energy depending upon their physiology and preference for substrate. The production of chitinase is inducible and affected by nature of substrate used in production. Therefore, the choice of an appropriate inducing substrate is of great importance. These solid substrates serve as support and/or nutrient source. As shown in Figure 2.7, different chitin substrate materials like a chitin, $\beta$ chitin, colloidal chitin as well as varying concentration of a chitin was tested for their successful utilization as substrate. Among different substrate tested with variable concentration, a chitin showed maximum enzyme activity with $0.5 \mathrm{~g} \%(\mathrm{w} / \mathrm{v})$ chitin concentration. The activity of chitinase was found to be maximum i.e $100 \mathrm{U} / \mathrm{ml}$. As a chitin gave maximum activity for the enzyme, hence it was used for further experiment with their particular concentration $0.5 \mathrm{~g} \%$.

\subsection{Effect of pH on chitinase production by Streptomyces ANU5a}

The hydrogen ion concentration has a marked effect on enzyme production. This may be due to stability of extracellular enzyme at this particular $\mathrm{pH}$ and the rapid denaturation at lower or higher $\mathrm{pH}$ values, which ultimately lowers the enzyme activity. Chitinases are fairly stable over broad pH range (Saber et al., 2015).

The $\mathrm{pH}$ stability of chitinase varies from organism to organism. The effect of different $\mathrm{pH}$ on chitinase production is depicted in Figure 2.8. Among the different $\mathrm{pH}$ checked, the maximum enzyme production $(61 \mathrm{U} / \mathrm{ml})$ was observed on $7^{\text {th }}$ day at $\mathrm{pH} 7 \mathrm{which}$ declined with further increasing initial pH. Similar results were observed by Sowmya et al. (2012) and Thiagarajan et al., 2011), who investigated that the chitinase from Streptomyces to be stable over a pH range of 4.0 to 10 .

\subsection{Effect of temperature on chitinase production by Streptomyces ANU5a}

The selection of temperature depends on the optimum growth temperature of the selected culture. As enzymes are primary metabolites, so their production is mainly related to growth. More the growth more will be the enzymes produced. The production of enzyme at different temperature $30^{\circ} \mathrm{C}$ and at $37^{\circ} \mathrm{C}$ was studied. As depicted in Figure 2.9 the optimum temperature for chitinase production is at $30^{\circ} \mathrm{C}$. It is found to be in mesophilic range. The chitinase was found to maximum as $42 \mathrm{U} / \mathrm{mL}$ at $30{ }^{\circ} \mathrm{C}$ supplemented with a chitin.

\subsection{Effect of nitrogen source on chitinase production by Streptomyces ANU5a}

The requirement of nitrogen source in the production medium of chitinases has been reported to vary considerably by various researchers. Production of chitinases is sensitive to nitrogen sources and nitrogen level in the medium. Few reports on nitrogen supplement in chitinase production medium indicates inhibitory effect (Suresh \& Chandrasekaran, 1998). In this study yeast extract and casein hydrolysate were used to optimize nitrogen sources for maximum chitinase production. BHM broth supplemented with varying concentration $(0.05 \mathrm{~g} \%$ to $0.2 \mathrm{~g} \%)$ of yeast extract and casein hydrolysate were used. As shown in Fig.2.10 A \& B, the enzyme was found to be enhanced when $0.05 \mathrm{~g} \%$ yeast extract and $0.2 \mathrm{~g} \%$ casein hydrolysate were applied as external source of nitrogen.

Present study indicates higher concentration of yeast extract and casein hydrolysate has inhibitory effect on chitinase production. They may contribute to fulfill the bacterial nitrogen demand much easily than chitin; it could be a reason for decrease in enzyme production at higher concentration.

\subsection{Effect of media component on chitinase production}

In this study, different media component were examined for maximum enzyme production. Result of this experiment as depicted in table (2.4) indicates; followed by addition of different media component into chitinase production medium, enzyme production was found to increase than without co-substrates. With one factor at a time approach, significant improvement in yield of enzyme could be achieved by media optimization which is summarized in Table 2.4 .

\subsection{ESEM Analysis}


Chitin degradation and cell morphology of Streptomycetes sp. ANU5a were analysed by using Environmental Scanning Electron Microscope (ESEM). The morphological examination of the degraded chitin flakes (Figure 2.10) using ESEM confirmed the degenerated native structure of the chitin flakes Moreover, the microbial chitinases resulted in degradation of chitin fiber which is visible as increased porosity of the substrate (Hao et al. 2016).

\subsection{Native PAGE and Zymogram Analysis}

The purified chitinase exhibited a three protein bands on Native-PAGE. The relative molecular weight of enzymes was approximately $20 \mathrm{kDa}$. Further identification of the target band was carried out by zymogram analysis as shown in Figure 2.11 .

After subjecting the partial purified enzyme of the Streptomyces sp ANU5a to zymogram analysis, three bands were exhibited $(240,67 \& 20 \mathrm{kDa})$, in which two bands were showing chitinase activity. The size of the chitinase activity bands exhibited in the zymogram is relatively small compared to that observed by Saadoun et al., (2009). Who reported the molecular mass of chitinase from Streptomyces (strain 242) to be $55 \mathrm{kDa}$ to $97 \mathrm{kDa}$.

\section{Discussion}

The association of decomposition of chitin and antifungal properties is described in earlier reports (Huang et al., 2005). So, in the present study, we screened and determine twenty five different chitinolytic actinomycete strains exhibiting strong chitinolytic activity based on chitinolysis on BHM agar plates. Selected strains were further screened for antagonistic properties of Aspergillus flavus,Fusarium oxysporium, and Magnaporthe oryzae. The result indicates the significant inhibition of the growth of phytopathogenic fungi on OMA plates by ANU5a, ANU5b, CAI155 and CAl155b strains. The inhibition pattern and zones of inhibition on the OMA plates links to the production of water-soluble antifungal metabolites by the active Actinomycetes strains. There are numerous studies to support the critical role of chitinolytic enzymes for antifungal properties in various strains. S. Y. Lee et al. (2012) reported the inhibition of the growth of Colletotrichum gloeosporioides, a pathogen that causes a fungal disease known as anthracnose in black pepper by chitinases purified from Streptomyces cavuerensis SY224. Kishore, Pande, and Podile (2005) reported the biological potential in controlling late Leaf Spot disease in peanuts (Arachis hypogaea) by chitinolytic bacterial strains B. circulans GRS 243 and S. marcescens GPS. Recently, it was reported by Nguyen et al. (2012) that Streptomyces griseus $\mathrm{H} 7602$ have considerable potential as a biocontrol in papper against root rot disease (Phytophthora capsici). Hoster, Schmitz, and Daniel (2005) also highlighted the role of purified chitinase from Streptomyces griseus MG3 strain as possible antifungal against the phytopathogenic fungi such as Aspergillus nidulans, Botrytis cinerea, Fusarium culmorum, Guignardia bidwellii and Sclerotia sclerotiorum. In a same way selected strain were studied for antifungal as well as chitinolytic activity. ANU5a was found to be an efficient strain, as well as possesses plant growth promotion traits along with its ability to secrete a range of extracellular hydrolytic enzymes. This strain was identified as Streptomyces sp. ANU5a. It would be worth considering this organism for further investigation with respect to its plant growth promoting and agronomic practices (Aam et al., 2010).

\section{Declarations}

\section{Acknowledgements}

We thank the faculty members of School of Biosciences, Sardar Patel University for their guidance and useful suggestions. The research work is plausibly supported by the funds from Department of Biotechnology, Government of India and BRD School of Biosciences for the laboratory facilities.

\section{Discription of Authors work:}

PKT: Conceptualization, Methodology, Software, Visualization,

Investigation, Writing- Original draft preparation,

SJM: Investigation, Data curation, Visualization, Writing- Original draft preparation, Writing-Reviewing and Editing. 
AA: Conceptualization, Methodology, Software, Data curation, Writing- Reviewing and Editing.

\section{Compliance with Ethical Standards:}

\section{Funding:}

No Funding

\section{Conflict of Interest:}

- All authors have participated in (a) conception and design, or analysis and interpretation of the data; (b) drafting the article or revising it critically for important intellectual content; and (c) approval of the final version.

- This manuscript has not been submitted to, nor is under review at, another journal or other publishing venue.

- The authors have no affiliation with any organization with a direct or indirect financial interest in the subject matter discussed in the manuscript

- The following authors have affiliations with organizations with direct or indirect financial interest in the subject matter discussed in the manuscript:

Author's name Affiliation

Piyush Kumar Tiwari Manager, Centyle Biotech Private Limited, Rudrapur

Shubhjeet Mandal Senior Executive, Centyle Biotech Private Limited

Anchal Research Scholar, University of Delhi South Campus

\section{Ethical approval:}

"This article does not contain any studies with human participants or animals performed by any of the authors."

\section{Data Availability Statement (DAS):}

"Data sharing is not applicable to this article as new data were created or analyzed in this study."

\section{Suggested Reviewers:}

- R B Subramanian, Associate professor, Sardar Patel University, Gujarat, India. Email: subramanianrb@gmail.com

- M. Nataraj, Assistant Professor, Sardar Patel University, Gujarat, India. Email: mnatarajspu@gmail.com

- Kamal Kumar Gupta, Associate Professor, Deshbandhu College, University of Delhi, New Delhi, India. Email: kgupta@db.du.ac.in

- Varsha Baweja, Associate Professor, Deshbandhu College, University of Delhi, New Delhi, India. Email: vbaweja@db.du.ac.in

\section{References}

1. Aam BB, Heggset EB, Norberg AL, S??rlie M, V??rum KM, Eijsink VGH (2010) Production of chitooligosaccharides and their potential applications in medicine. Mar Dru 8(5):1482-1517. https://doi.org/10.3390/md8051482

2. Agrawal T, Kotasthane AS (2012) Chitinolytic assay of indigenous Trichoderma isolates collected from different geographical locations of Chhattisgarh in Central India. SprinPlus 1(1):1-10

3. Ahmad F, Ahmad I, Khan MS (2008) Screening of free-living rhizospheric bacteria for their multiple plant growth promoting activities. Micro Res 163(2):173-181. https://doi.org/10.1016/j.micres.2006.04.001 
4. Aida FM, Al-Nusarie S, Taghreed S (2014) Production, optimization, characterization and antifungal activity of chitinase produced by Aspergillus terrus. Afr. Jou. of Bioteh., 13(14)

5. Anil K, Seshagirirao K, Podile AR (2007) A simple, rapid and yet less expensive method to detect chitinase in agarose plates. $\mathrm{J}$ of Biochem Biophy Meth 70(4):683-684. https://doi.org/10.1016/j.jbbm.2007.01.015

6. Anné J, Vrancken K, Van Mellaert L, Van Impe J, Bernaerts K (2014 Aug) Protein secretion biotechnology in Gram-positive bacteria with special emphasis on Streptomyces lividans. Biochim Biophys Acta 1843(8):1750-1761. doi:10.1016/j.bbamcr.2013.12.023. Epub 2014 Jan 9. PMID: 24412306

7. Bonjar GS, Zarandi ME, Dehkaei FP, Moosavi SA, Farokhi PR, Aghighi S (2009) Biological control of rice blast (Magnaporthe oryzae) by use of Streptomyces sindeneusis isolate 263 in greenhouse. Amer J of Appl Sc 6(1):194-199

8. Caceres I, Snini SP, Puel O, Mathieu F (2018) Streptomyces roseolus, A Promising Biocontrol Agent Against Aspergillus flavus, the Main Aflatoxin Bâه Producer. Tox 10(11):442. https://doi.org/10.3390/toxins10110442

9. Dahiya N, Tewari R, Tiwari RP, Hoondal GS (2005) Chitinase production in solid-state fermentation by Enterobacter sp. NRG4 using statistical experimental design. Curr Micro 51(4):222-228. https://doi.org/10.1007/s00284-005-4520-y

10. Gherbawy Y, Elhariry H, Altalhi A, El-Deeb B, Khiralla G (2012) Molecular screening of Streptomyces isolates for antifungal activity and family 19 chitinase enzymes. J of Micro 50(3):459-468. https://doi.org/10.1007/s12275-012-2095-4

11. Gopalakrishnan S, Humayun P, Kiran BK, Kannan IGK, Vidya MS, Deepthi K, Rupela O (2011) Evaluation of bacteria isolated from rice rhizosphere for biological control of charcoal rot of sorghum caused by Macrophomina phaseolina (Tassi) Goid. W $\mathrm{J}$ of Micro Biotech 27(6):1313-1321. https://doi.org/10.1007/s11274-010-0579-0

12. Gopalakrishnan S, Pande S, Sharma M, Humayun P, Kiran BK, Sandeep D, ... Rupela O (2011) Evaluation of actinomycete isolates obtained from herbal vermicompost for the biological control of Fusarium wilt of chickpea. Crop Prot 30(8):10701078

13. Halder SK, Maity C, Jana A, Ghosh K, Das A, Paul T, Mohapatra PK, Das, Pati BR, Mondal KC (2014) Chitinases biosynthesis by immobilized Aeromonas hydrophila SBK1 by prawn shells valorization and application of enzyme cocktail for fungal protoplast preparation. J of Biosc Bioeng 117(2):170-177. https://doi.org/10.1016/j.jbiosc.2013.07.011

14. Hao Z, Wu H, Yang M, Chen J, Xi L, Zhao W, Yu J, Liu J, Liao X, Huang Q (2016) Cloning, Expression and 3D Structure Prediction of Chitinase from Chitinolyticbacter meiyuanensis SYBC-H1. Int j of mol sc 17(6):825.

https://doi.org/10.3390/ijms17060825

15. Hoster F, Schmitz JE, Daniel R (2005) Enrichment of chitinolytic microorganisms: Isolation and characterization of a chitinase exhibiting antifungal activity against phytopathogenic fungi from a novel Streptomyces strain. App Micro Biotech 66(4):434-442. https://doi.org/10.1007/s00253-004-1664-9

16. Hrdý J, Súkeníková L, Petrásková P, Novotná O, Kahoun D, Petříček M, Chroňáková A, Petříčková K (2020) Inhibition of proinflammatory cytokines by metabolites of streptomycetes-a potential alternative to current anti-inflammatory drugs? Microorg, 8(5). https://doi.org/10.3390/microorganisms8050621

17. Huang C-J, Wang T-K, Chung S-C, Chen C-Y (2005) Identification of an antifungal chitinase from a potential biocontrol agent, Bacillus cereus 28 - 9. J of Bioche Mol Bio 38(1):82-88. https://doi.org/10.5483/BMBRep.2005.38.1.082

18. Itoh T, Hibi T, Fujii Y, Sugimoto I, Fujiwara A, Suzuki F, Iwasaki Y, Kim JK, Taketo A, Kimoto H (2013) Cooperative degradation of chitin by extracellular and cell surface-expressed chitinases from Paenibacillus sp. strain FPU-7. App Env Micro 79(23):7482-7490. https://doi.org/10.1128/AEM.02483-13

19. Jayamurthy H, Sajna KV, Dastagar SG, Pandey A (2014) Anti-fungal potentials of extracellular metabolites of Western Ghats isolated Streptomyces sp. NII 1006 against moulds and yeasts. Ind J of Exp Bio 52(11):1138-1146

20. Karaba SM, White RC, Cianciotto NP (2013) Stenotrophomonas maltophilia encodes a Type II protein secretion system that promotes detrimental effects on lung epithelial cells. Inf Imm 81(9):3210-3219. https://doi.org/10.1128/IAI.00546-13

21. Khamna S, Yokota A, Lumyong S (2009) Actinomycetes isolated from medicinal plant rhizosphere soils: diversity and screening of antifungal compounds, indole-3-acetic acid and siderophore production. W J of Micro Biotech 25(4):649-655

22. Kielak AM, Cretoiu MS, Semenov AV, Sørensen SJ, Van Elsas JD (2013) Bacterial chitinolytic communities respond to chitin and pH alteration in soil. App EnvMicro 79(1):263-272. https://doi.org/10.1128/AEM.02546-12

Page $11 / 23$ 
23. Kishore GK, Pande S, Podile aR (2005) Biological Control of Late Leaf Spot of Peanut (Arachis hypogaea) with Chitinolytic Bacteria. Phytopath 95(10):1157-1165. https://doi.org/10.1094/PHYTO-95-1157

24. Lee SY, Tindwa H, Lee YS, Naing KW, Hong SH, Nam Y, Kim KY (2012) Biocontrol of anthracnose in pepper using chitinase, ??-1,3 glucanase, and 2-furancarboxaldehyde produced by Streptomyces cavourensis SY224. J of Micro Biotech 22:13591366. https://doi.org/http://dx.doi.org/10.4014/jmb.1203.02056

25. Lee W, van Baalen M, Jansen VAA (2012) An evolutionary mechanism for diversity in siderophore-producing bacteria. Eco Lett 15(2):119-125. https://doi.org/10.1111/j.1461-0248.2011.01717.x

26. Li X, Roseman S (2004) The chitinolytic cascade in Vibrios is regulated by chitin oligosaccharides and a two-component chitin catabolic sensor/kinase. Proc. of the Nat. Aca. of Sc. of the USA, 101(2), 627-631.

https://doi.org/10.1073/pnas.0307645100

27. Mehmood MA, Xiao X, Hafeez FY, Gai Y, Wang F (2011) Molecular characterization of the modular chitin binding protein Cbp50 from Bacillus thuringiensis serovar konkukian. A V L 100(3):445-453

28. Nguyen XH, Naing KW, Lee YS, Tindwa H, Lee GH, Jeong BK, ... Kim KY (2012) Biocontrol potential of Streptomyces griseus H7602 against root rot disease (Phytophthora capsici) in pepper. The Plant Path J 28(3):282-289

29. Okazaki K, Yamashita Y, Noda M, Sueyoshi N, Kameshita I, Hayakawa S (2004) Molecular cloning and expression of the gene encoding family 19 chitinase from Streptomyces sp. J-13-3. Bio Biotechy Biochem 68(2):341-351. https://doi.org/10.1271/bbb.68.341

30. Purushotham P, Sarma PVSRN, Podile AR (2012) Multiple chitinases of an endophytic Serratia proteamaculans 568 generate chitin oligomers. Biores Tech 112:261-269. https://doi.org/10.1016/j.biortech.2012.02.062

31. Saadoun I, Al-Omari R, Jaradat Z, Ababneh Q (2009) Influence of culture conditions of Streptomyces sp. (strain S 242) on chitinase production. Pol $\mathrm{j}$ of micro 58:339-345

32. Saber WIA, Ghoneem KM, Al-Askar AA et al (2015) Chitinase Production by bacillus Subtilis ATCC 11774 and its Effect on Biocontrol of Rhizoctonia Diseases of Potato. BIO FUT 66:436-448. https://doi.org/10.1556/018.66.2015.4.8

33. Sharma S, Kumar V, Tripathi R (2017) Isolation of phosphate solubilizing microorganism (PSMs) from soil. J of Micro Biotech Res 1:90-95

34. Suresh PV, Chandrasekaran M (1998) Utilization of prawn waste for chitinase production by the marine fungus Beauveria bassiana by solid state fermentation. W J of Micro Biotech 14(5):655-660

35. Swiontek Brzezinska M, Jankiewicz U, Burkowska A, Walczak M (2014) Chitinolytic microorganisms and their possible application in environmental protection. Curr Micro 68(1):71-81. https://doi.org/10.1007/s00284-013-0440-4

36. Thiagarajan V, Revathi R, Aparanjini K, Sivamani P, Girilal M, Priya CS, Kalaichelvan PT (2011) Extra cellular chitinase production by Streptomyces sp. PTK19 in submerged fermentation and its lytic activity on Fusarium oxysporum PTK2 cell wall. Int J Curr Sci 1:30-44

37. Wang W, Xie ZP, Staehelin C (2014) Functional analysis of chimeric lysin motif domain receptors mediating Nod factorinduced defense signaling in Arabidopsis thaliana and chitin-induced nodulation signaling in Lotus japonicus. PI J 78(1):56-69. https://doi.org/10.1111/tpj.12450

38. Worsley SF, Newitt J, Rassbach J, Batey SFD, Holmes NA, Murrell JC, Wilkinson B, Hutchings MI (2020) Streptomyces endophytes promote host health and enhance growth across plant species. App Env Micro 86(16):1-17. https://doi.org/10.1128/AEM.01053-20

39. Zarandi ME, Bonjar GS, Dehkaei FP, Moosavi SA, Farokhi PR, Aghighi S (2009) Biological control of rice blast (Magnaporthe oryzae) by use of Streptomyces sindeneusis isolate 263 in greenhouse. Ame J of App Sc 6(1):194-199

\section{Tables}


Table 1: Major chitinase producers and their antifungal activity

\section{Source of chitinases}

Trichoderma harzianum Rifai TM

Trichoderma harzianum Macrophomina phaseolina, Fusarium sp. R. solani, Aspergillus niger (NCIM 563),

Aspergillus, Rhizopus, Mucor sp.

Trichoderma atroviride Rhizoctonia solani PTCC5220

Brevibacillus laterosporus

Bacillus thuringiensis subsp. colmeri $15 A 3$

Aeromonas hydrophila SBK1

Enterobacter sp. NRG4

Alcaligenes

xylosoxydans

Stenotrohomonas

maltophila

Rhizobium $s p$

Serratia marcescens strain B2

Vibrio spp.

Streptomyces

hygroscopicus

Streptomyces tendae Aspergillus niger, F. oxysporum

TK-VL_333

Streptomyces sp. $S 242$

Streptomyces roseolus GH18

Streptomyces

sporovirgulis

Streptomyces plicatus

Streptomycetes grisus H7602

Streptomyces

sudanenesis

Antagonistic against

Fusarium equiseti Penicillium glaucum, Sclerotinia fuckelian

Aspergillus flavus, F. oxysporum Rhizopus nigricans

Fusarium sp. Rhizoctonia bataticola oxysporum, Fusarium udum

Botrytis cinerea Zygorhynchus heterognmus

Colletotrichum gloeosporioides, Sclerotium rolfsii

Aspergillus niger, Candida albicans Mucor spp.

Alternaria alternata

Alternaria alternata, F. solani

Phytophthora capsici

Magnaporthe oryzae
Fusarium oxysporum $f$. sp. melonis, Sclerotium rolfsii

Rhizoctonia solani, B. cinerea, P. chrysogenum, P. piricola,

Fusarium moniliforme, Aspergillus niger, Mucor rouxi,

Fusarium solani, F. oxysporum, R. solani, A. alternata

Aspergillus flavus, Aspergillus niger, Curvularia lunata, F.

Mucor racemosus, , Candida albicans, Trichoderma viride,

Aspergillus spp., Rhizopus chinensis, Penicillium spp.,
(Saadoun et al., 2009)

(Bonjar et al., 2001)

\section{References}

(Okazaki et al., 2004)

(Swiontek Brzezinska et al., 2014)

(Agrawal \& Kotasthane, 2012)

(Gopalakrishnan, Humayun, et al., 2011)

(Mehmood et al., 2011)

(Halder et al., 2014)

(Dahiya et al., 2005)

(Swiontek Brzezinska et al., 2014)

(Karaba et al., 2013)

(Wang et al., 2014)

(Purushotham et al., 2012)

(Li \& Roseman, 2004)

(Swiontek Brzezinska et al., 2014)

(Gherbawy et al., 2012)

(Streptomyces Roseolus-GH18 (Jiang et Al 2012).Pdf, n.d.)

(Swiontek Brzezinska et al., 2014)

(Nguyen et al., 2012)

(Zarandi et al., 2009) 


\begin{tabular}{|c|c|c|c|}
\hline Bacterial isolates & Aspergillus flavus & Fusarium oxysporium & Magnaporthe oryzae \\
\hline $\mathrm{AC} 1$ & + & + & - \\
\hline AC2 & + & + & - \\
\hline AC3 & ++ & ++ & - \\
\hline AC4 & + & - & - \\
\hline AC5 & - & - & - \\
\hline AC7 & + & - & - \\
\hline CAI 155a & +++ & + & + \\
\hline CAI 155b & +++ & + & - \\
\hline CAI 127 & + & - & + \\
\hline KAI 90 & - & - & - \\
\hline CAI 17 & - & - & - \\
\hline CAI 27B & - & - & - \\
\hline CAI 140B & - & - & ++ \\
\hline CAI 93B & - & - & - \\
\hline CAI 13A & +++ & + & - \\
\hline ANU 18 & +++ & + & - \\
\hline KAI 27B & + & - & - \\
\hline KAI 180B & - & - & - \\
\hline CAI 93C & - & - & - \\
\hline ANU 5A & +++ & + & ++ \\
\hline ANU 5B & +++ & + & ++ \\
\hline ANU 3 & + & - & - \\
\hline ANU 7B & - & - & - \\
\hline ANU 32 & - & ++ & - \\
\hline ANU 21 & - & ++ & - \\
\hline
\end{tabular}

Table 2.2: Plant growth promoting traits of Bacterial isolates 


\begin{tabular}{|c|c|c|c|c|c|c|c|c|c|}
\hline \multirow[b]{2}{*}{ Isolates } & \multicolumn{4}{|l|}{ PGPR traits } & \multicolumn{5}{|c|}{ Extracellular lytic enzyme production } \\
\hline & $\begin{array}{l}\text { Indole acetic } \\
\text { acid }\end{array}$ & $\begin{array}{l}\text { Phosphate } \\
\text { solubilization }\end{array}$ & Siderophore & $\mathrm{HCN}$ & Chitinase & Cellulase & Lipase & Protease & Amylase \\
\hline AC1 & - & - & - & - & ++ & & & + & + \\
\hline AC2 & + & - & + & + & - & & & ++ & ++ \\
\hline AC3 & + & - & - & - & - & & & ++ & ++ \\
\hline AC4 & $++(40 \mu \mathrm{g} / \mathrm{mL})$ & - & - & ++ & - & & & ++ & + \\
\hline AC5 & - & - & - & + & ++ & & & ++ & + \\
\hline AC7 & + & - & + & - & + & & & ++ & + \\
\hline $\begin{array}{l}\text { CAI } \\
155 a\end{array}$ & $\stackrel{+}{(27.7 \mu \mathrm{g} / \mathrm{mL})}$ & - & ++ & ++ & ++ & +++ & ++ & ++ & ++ \\
\hline $\begin{array}{l}\text { CAI } \\
155 b\end{array}$ & $++(55 \mu \mathrm{g} / \mathrm{mL})$ & - & ++ & ++ & ++ & ++ & + & ++ & + \\
\hline CAI 127 & - & - & + & ++ & ++ & & & ++ & + \\
\hline KAI 90 & + & ++ & + & - & ++ & & & ++ & - \\
\hline CAI 17 & $\stackrel{++}{(30.5 \mu \mathrm{g} / \mathrm{mL})}$ & - & - & ++ & - & & & ++ & - \\
\hline $\begin{array}{l}\text { CAI } \\
27 \mathrm{~B}\end{array}$ & - & - & - & - & - & & & ++ & ++ \\
\hline $\begin{array}{l}\text { CAI } \\
140 B\end{array}$ & + & + & - & - & - & & & ++ & - \\
\hline $\begin{array}{l}\text { CAl } \\
93 \mathrm{~B}\end{array}$ & - & - & - & + & + & & & & \\
\hline $\begin{array}{l}\text { CAl } \\
13 \mathrm{~A}\end{array}$ & $\stackrel{++}{(30.7 \mu \mathrm{g} / \mathrm{mL})}$ & + & + & + & + & & & & \\
\hline ANU 18 & + & - & + & + & ++ & & & & \\
\hline $\begin{array}{l}\text { KAl } \\
27 \mathrm{~B}\end{array}$ & - & - & - & - & - & & & & \\
\hline $\begin{array}{l}\mathrm{KAI} \\
180 \mathrm{~B}\end{array}$ & - & - & - & + & ++ & & & & \\
\hline $\begin{array}{l}\text { CAI } \\
93 \mathrm{C}\end{array}$ & - & - & + & - & + & & & & \\
\hline ANU 5A & $\begin{array}{l}\stackrel{++}{(24.5 \mu \mathrm{g} / \mathrm{mL})}\end{array}$ & + & ++ & ++ & ++ & +++ & + & +++ & ++ \\
\hline ANU 5B & $\begin{array}{l}++ \\
(19.75 \mu \mathrm{g} / \mathrm{mL})\end{array}$ & + & + & + & ++ & ++ & - & ++ & +++ \\
\hline ANU 3 & + & + & + & + & + & & & - & \\
\hline ANU7B & - & ++ & - & - & ++ & & & - & \\
\hline ANU 32 & - & ++ & - & - & - & & & - & \\
\hline ANU 21 & - & - & - & - & - & & & & \\
\hline
\end{tabular}

Table 2.3: chitinolytic Activity of the isolates in presence of solvents 


\begin{tabular}{|lllll|}
\hline Solvents & ANU5a & ANU5b & CAl 155a & CAl 155b \\
Control (without solvent) & + & + & + & + \\
\hline Methanol & - & - & - & - \\
\hline Acetone & - & - & - & - \\
\hline Benzene & - & - & - & - \\
\hline Toluene & - & - & - & - \\
\hline Dichloromethane & - & - & - & - \\
Cyclohexane & + & + & + & + \\
N-Hexane & + & + & + & + \\
\hline Iso-octane & ++ & + & + & + \\
Xylene & + & - & + & + \\
\hline
\end{tabular}

Table 2.4: Effect of media on enzyme production

\begin{tabular}{|c|c|c|c|c|c|}
\hline S.No & Production medium & Concentration of media component ( $\mathrm{g} \%)$ & $\begin{array}{l}\text { Incubation time } \\
\text { (h) }\end{array}$ & Units/ml & $\begin{array}{l}\text { Fold increase } \\
\text { (X) }\end{array}$ \\
\hline 1 & 1 & $\mathrm{BHM}+0.1 \mathrm{~g}$ chitin & $120 \mathrm{~h}$ & 5.2 & 1 \\
\hline 2 & $\|$ & $\mathrm{BHM}+0.1 \mathrm{~g}$ chitin $+0.1 \mathrm{YE}$ & $144 \mathrm{~h}$ & 31.3 & 6 \\
\hline 3 & III & $\mathrm{BHM}+0.5 \mathrm{~g}$ chitin $+0.1 \mathrm{~g} \mathrm{YE}+0.1 \mathrm{~g} \mathrm{CH}$ & $144 \mathrm{~h}$ & 62 & 11 \\
\hline 4 & IV & $\mathrm{BHM}+0.5 \mathrm{~g}$ chitin $+0.1 \mathrm{~g} \mathrm{YE}+0.2 \mathrm{~g} \mathrm{CH}$ & $120 \mathrm{~h}$ & 78 & 15 \\
\hline 5 & V & $\mathrm{BHM}+0.5 \mathrm{~g}$ chitin $+0.15 \mathrm{~g} \mathrm{YE}+0.2 \mathrm{~g} \mathrm{CH}$ & $144 \mathrm{~h}$ & 96.5 & 18.55 \\
\hline
\end{tabular}

Figures 

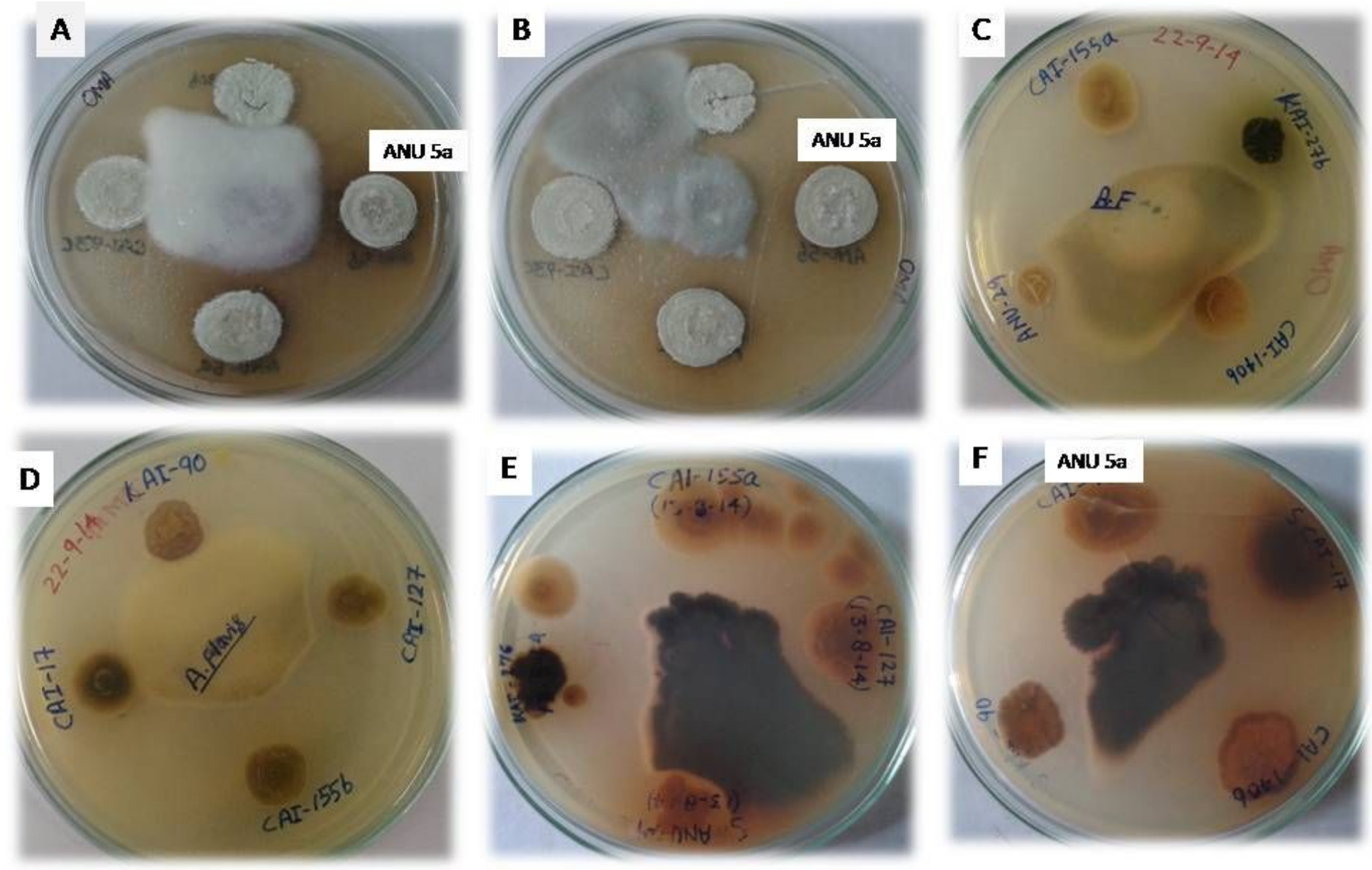

\section{Figure 1}

Inhibition of test fungi by the actinobacterial cultures: inhibition of (a) Fusarium oxysporum by strain ANU 5a \& ANU 5b, (B) Aspergillus flavus by strain ANU 5a \& ANU 5b, (C) A. flavus by strain CAI 155a, (D) A. flavus by strain CAI 155b, (E) Magnaporthe oryzae by CAI 155a, CAI 127 \& KAl 27b, (F) Magnaporthe oryzae by CAI 155b, CAI 140b \& KAI 90. 

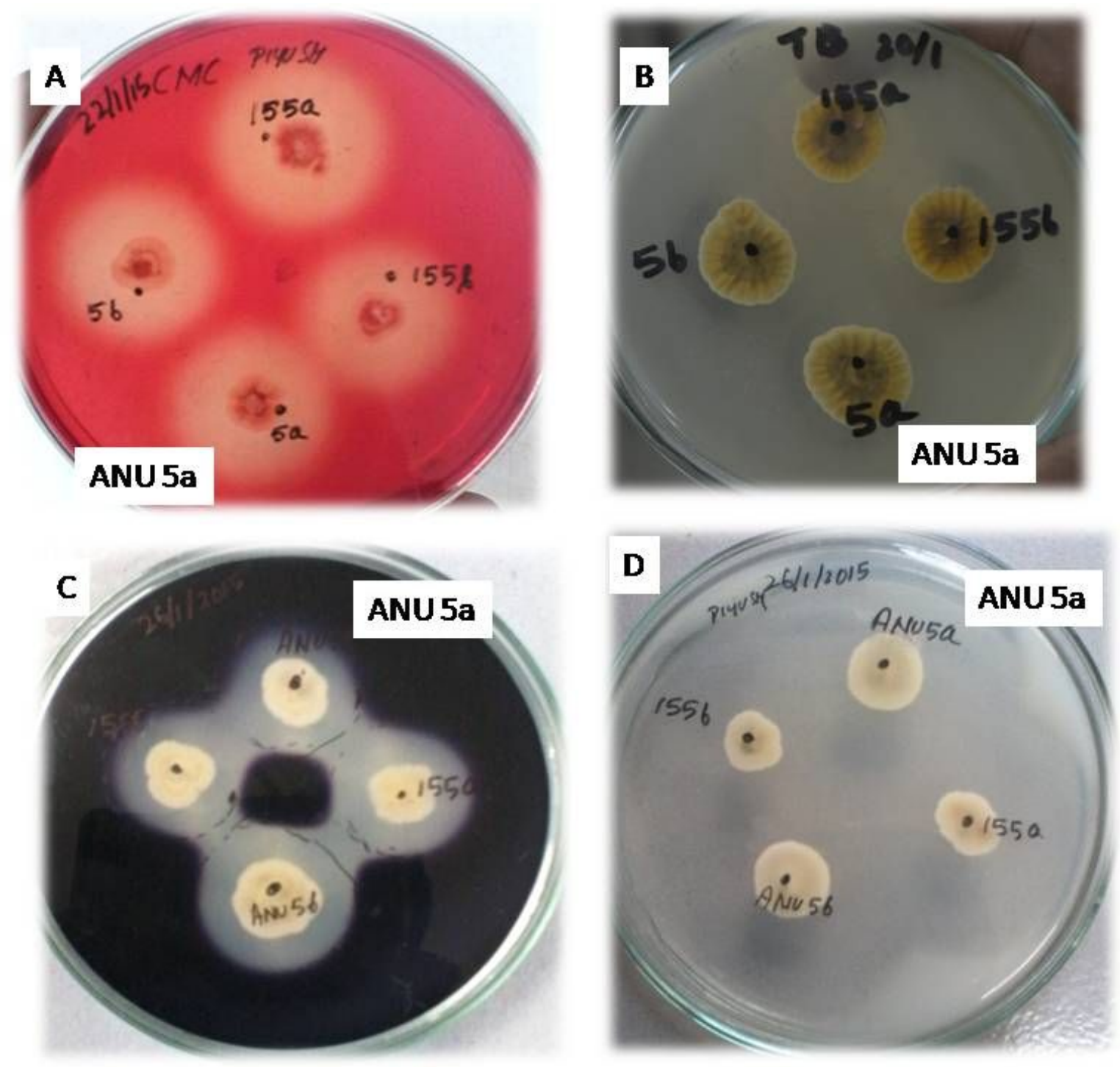

\section{Figure 2}

Plates showing extracellular enzyme production, (A) CMC agar plate for cellulase activity, (B) Tributyrin agar plate for lipase activity, (C) Starch agar plate for amylase activity, (D) Gelatin agar plate for protease activity. 


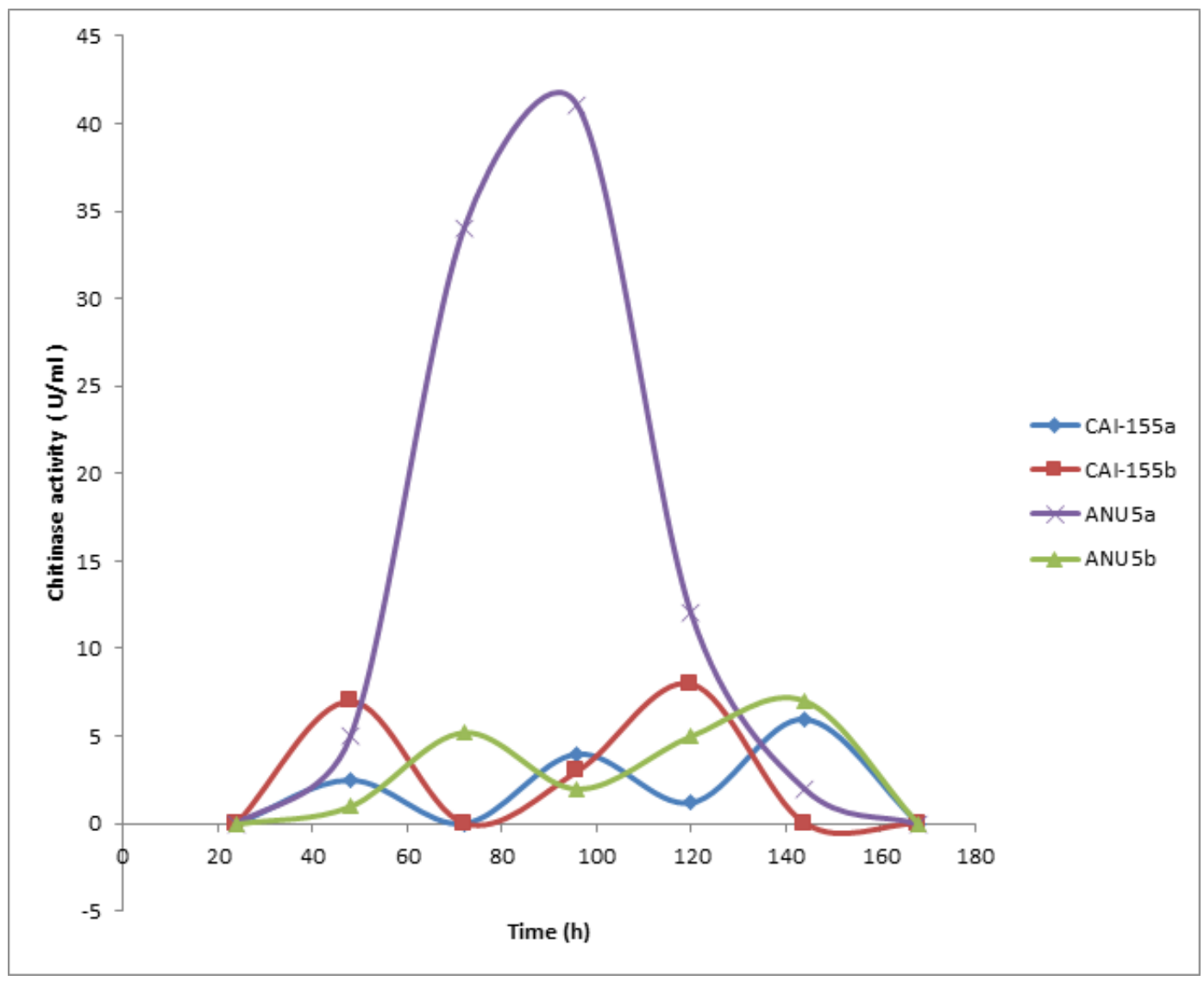

Figure 3

Chitinase Activity of promising Actinomycetes isolates.

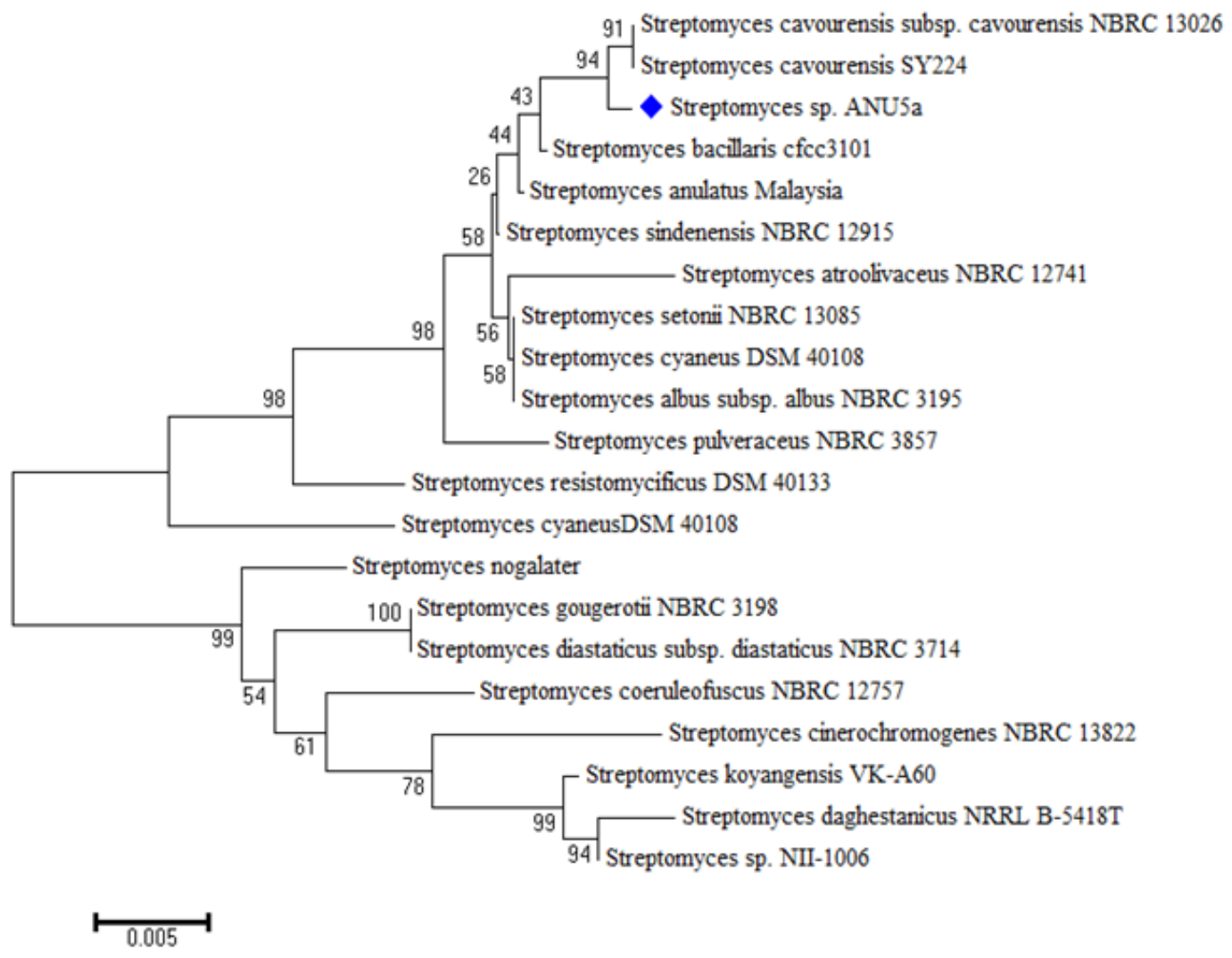

Figure 4 
Phylogenetic tree based on 16S rDNA gene sequences from strain ANU5a and other related organisms constructed using the neighbor-joining algorithm. (The tree was validated by bootstrap analysis (1,000 replications). Bar, 0.005 substitutions per 100 nucleotides.

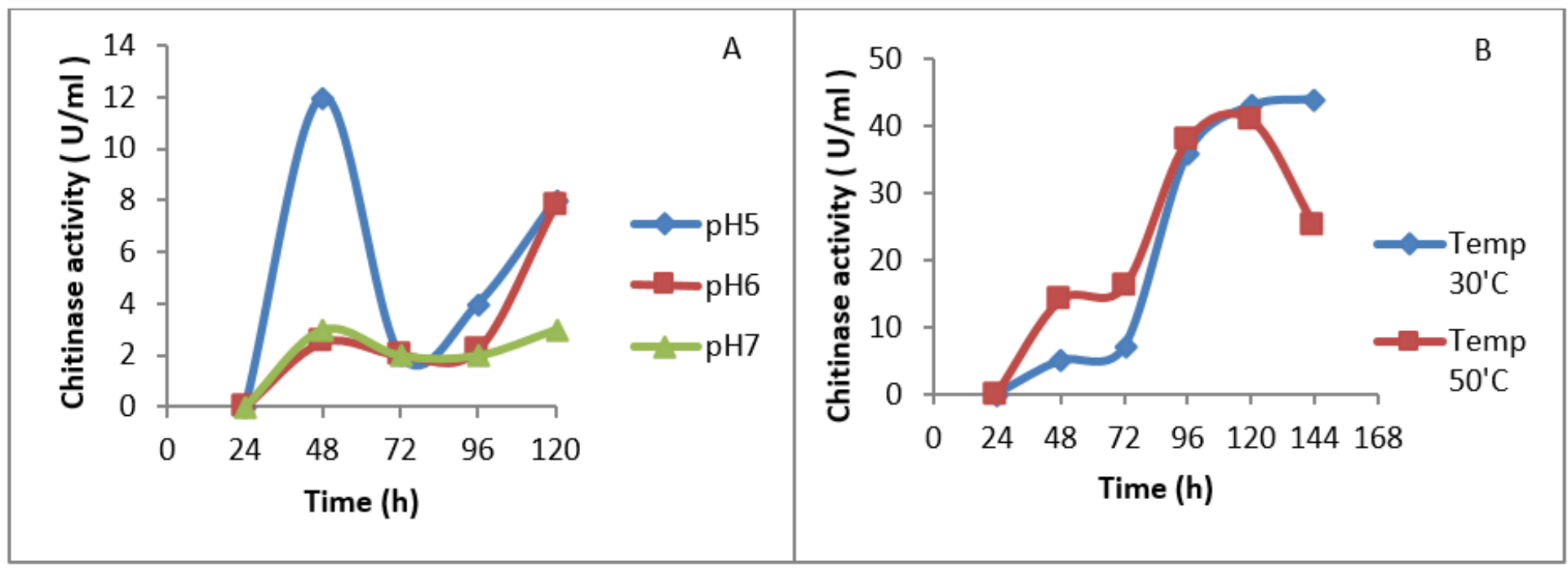

Figure 5

Effect of $\mathrm{pH}(\mathrm{A})$ and temperature (B) on chitinase activity.

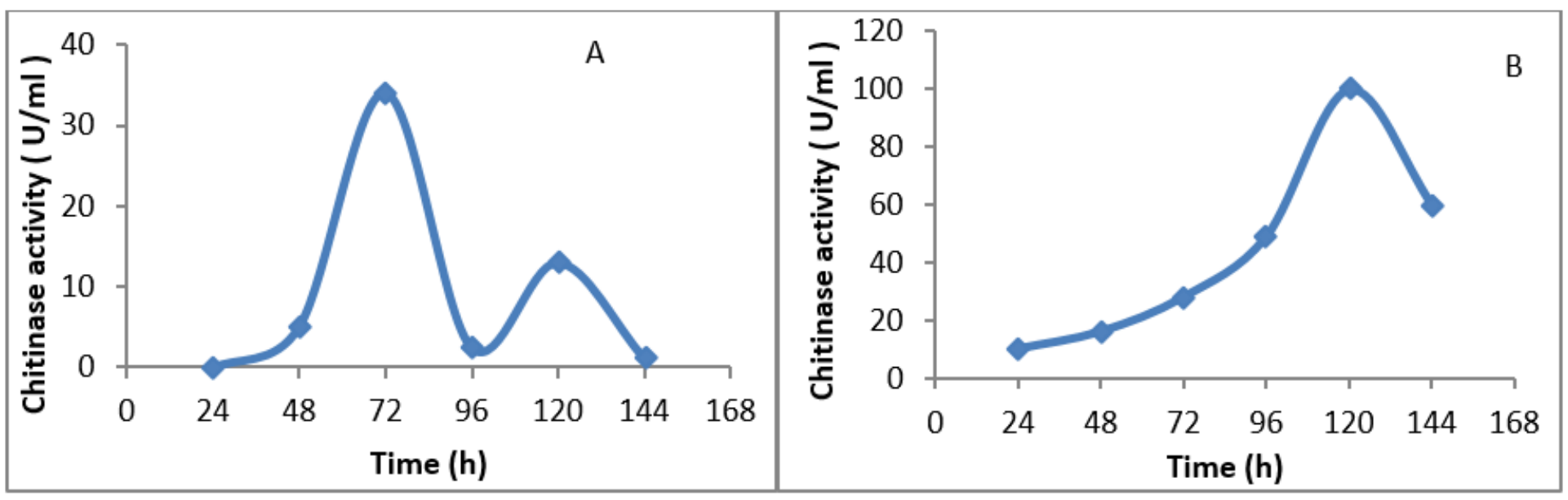

Figure 6

Effect of incubation period on chitinase (a) without additional supplement and (b) with additional supplements (Casein hydrolysate, yeast extract). 


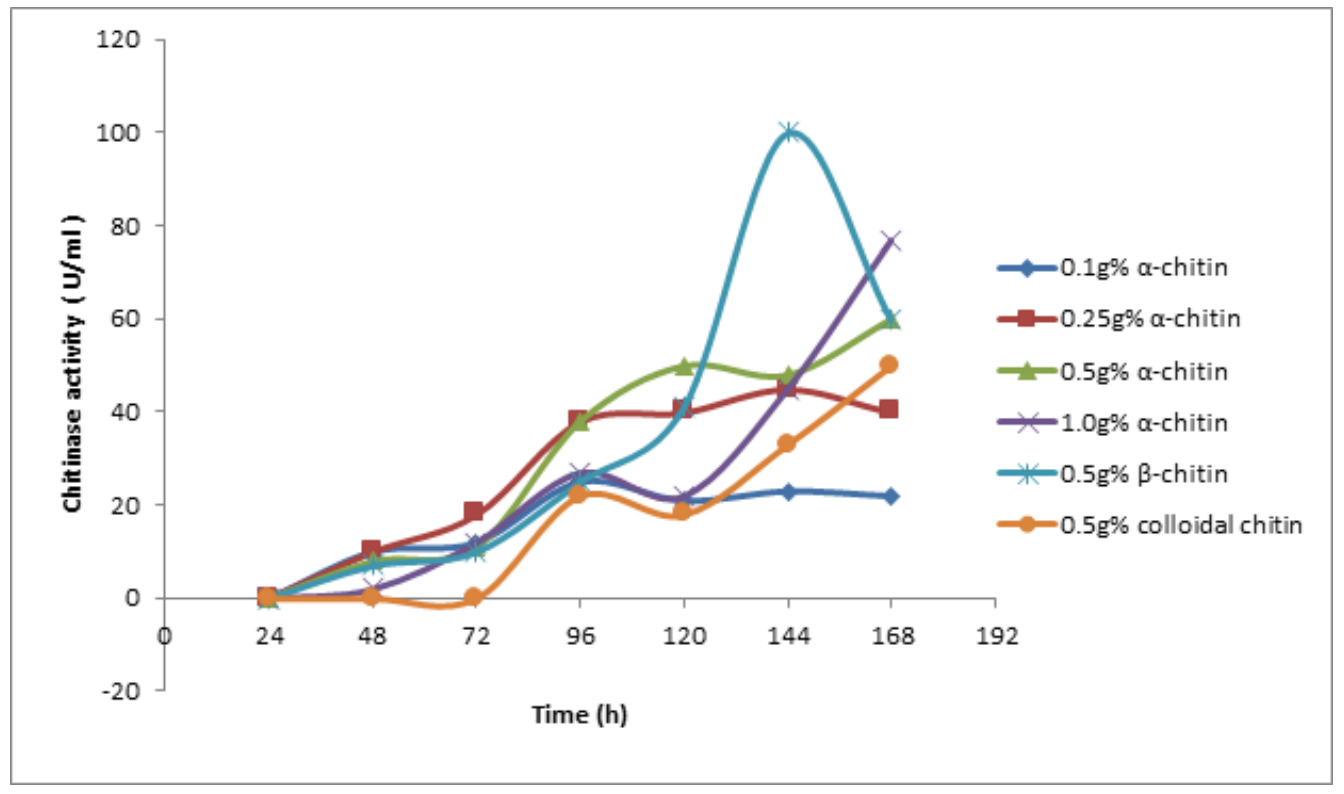

\section{Figure 7}

Effect of different chitin substrate material (A: $0.1 \mathrm{~g} \%$ a-chitin, B: $0.25 \mathrm{~g} \%$ a-chitin, C $0.5 \mathrm{~g} \%$ a-chitin, D: $1 \mathrm{~g} \%$ a-chitin, E:a-chitin, F:colloidal chitin) on chitinase production by Streptomyces sp. ANU5a.

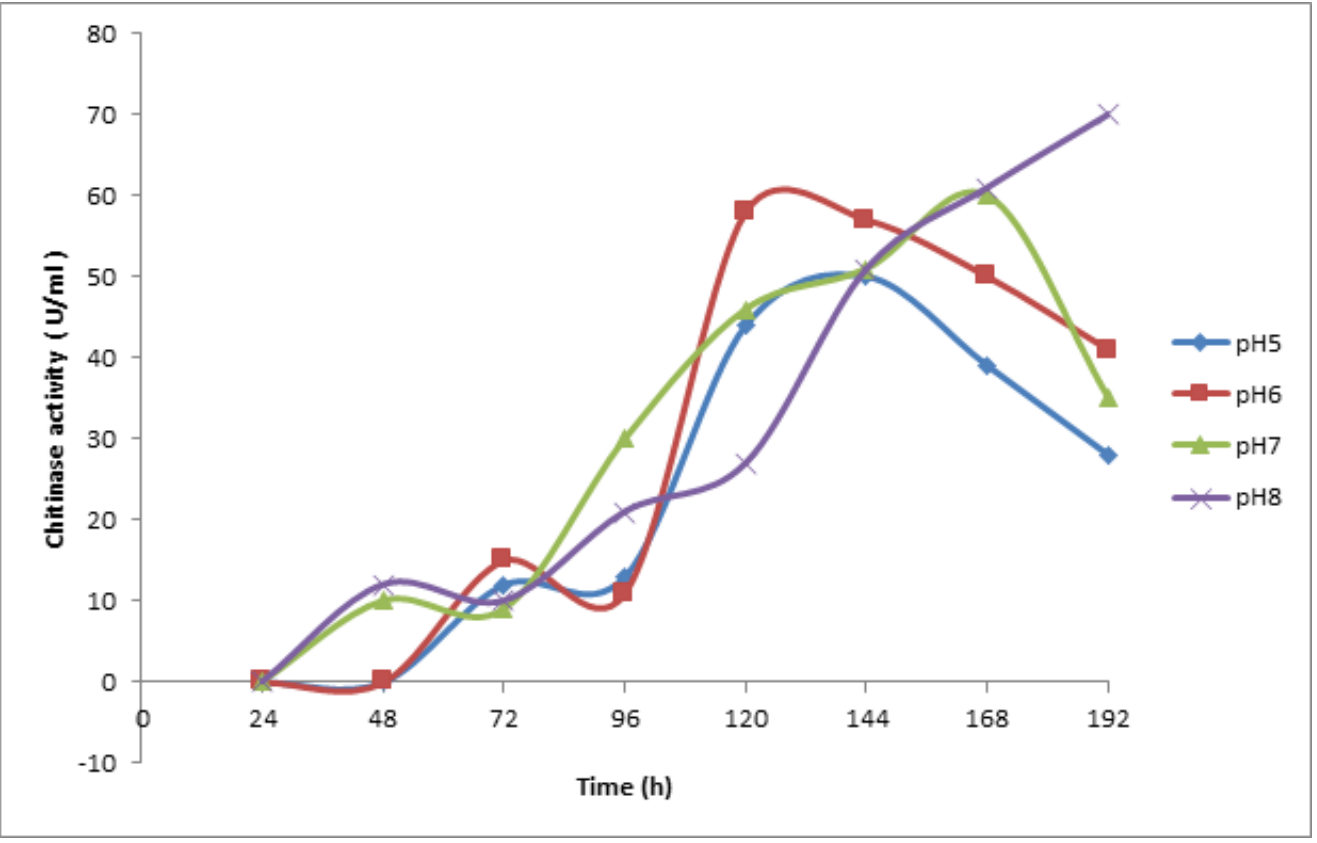

\section{Figure 8}

Effect of $\mathrm{pH}$ on chitinase production. 


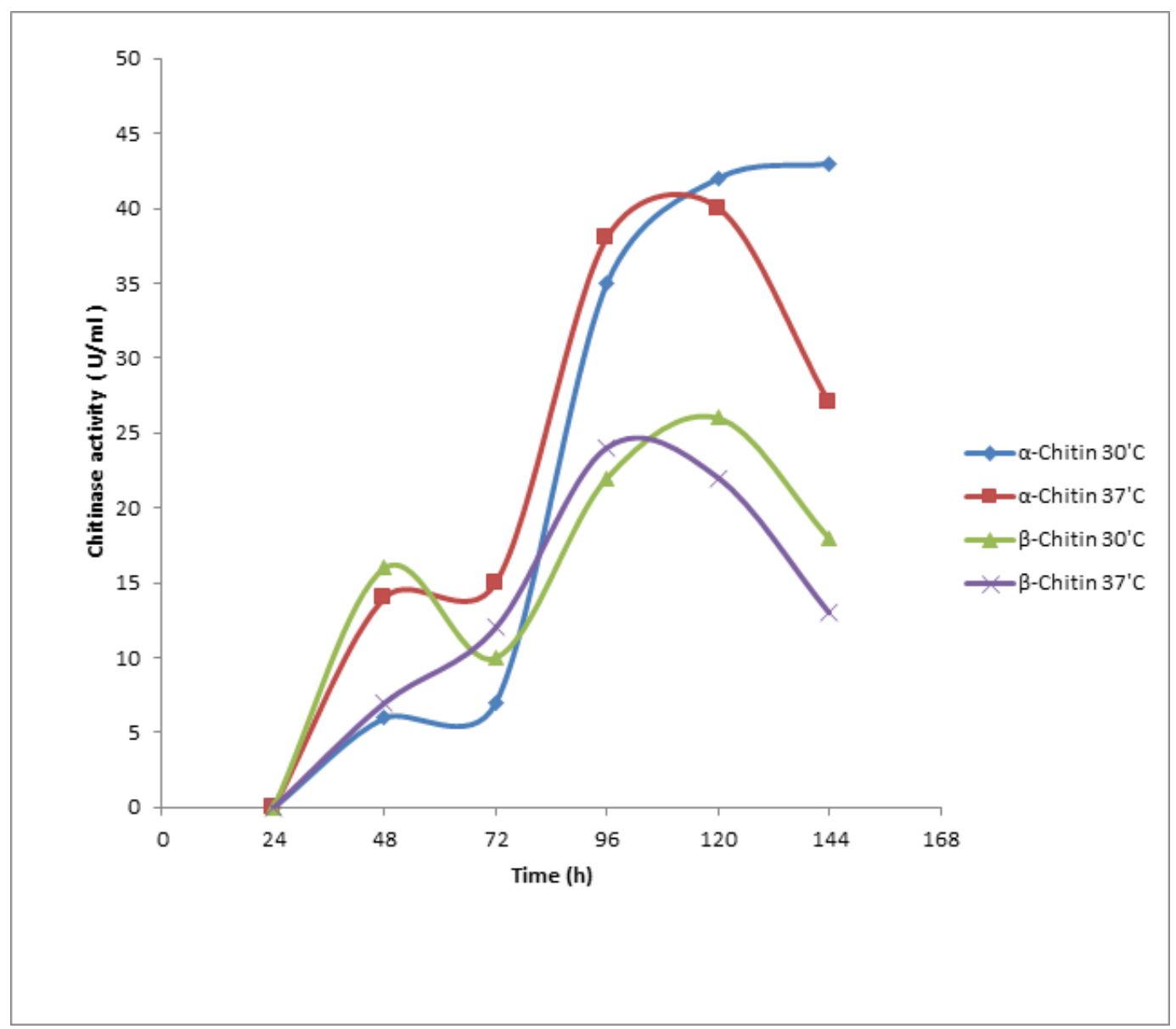

Figure 9

Effect of temperature on chitinase production.

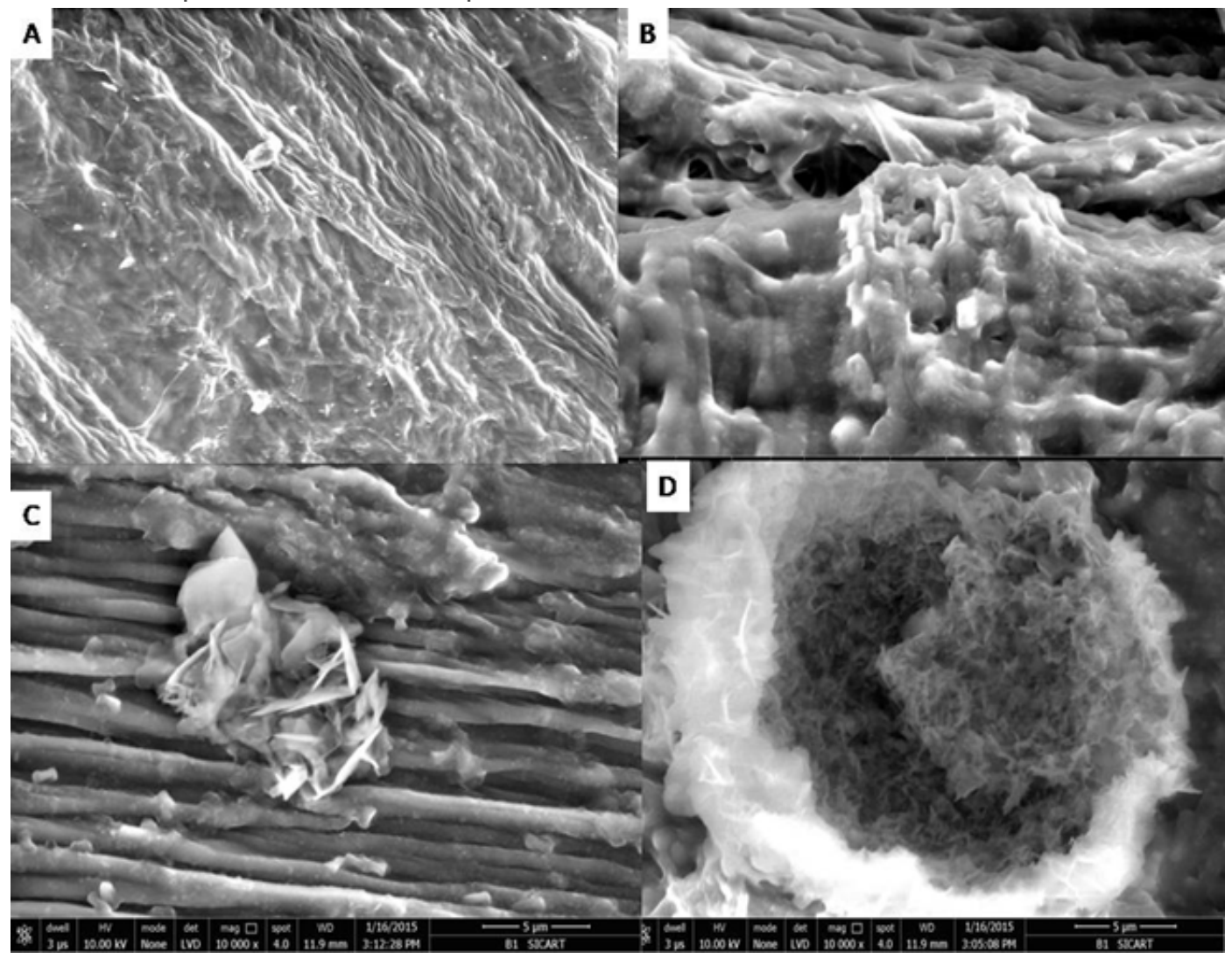


Figure 10

Chitin degradation by Streptomyces sp. ANU5a. (A) Control sample: without inoculation (B) ANU5a treated $\beta$-chitin flaks, (C) Adhesion of Streptomyces sp. ANU5a on chitin flaks (D) Chitinolytic action of Streptomyces sp. ANU 5a on chitin flaks.

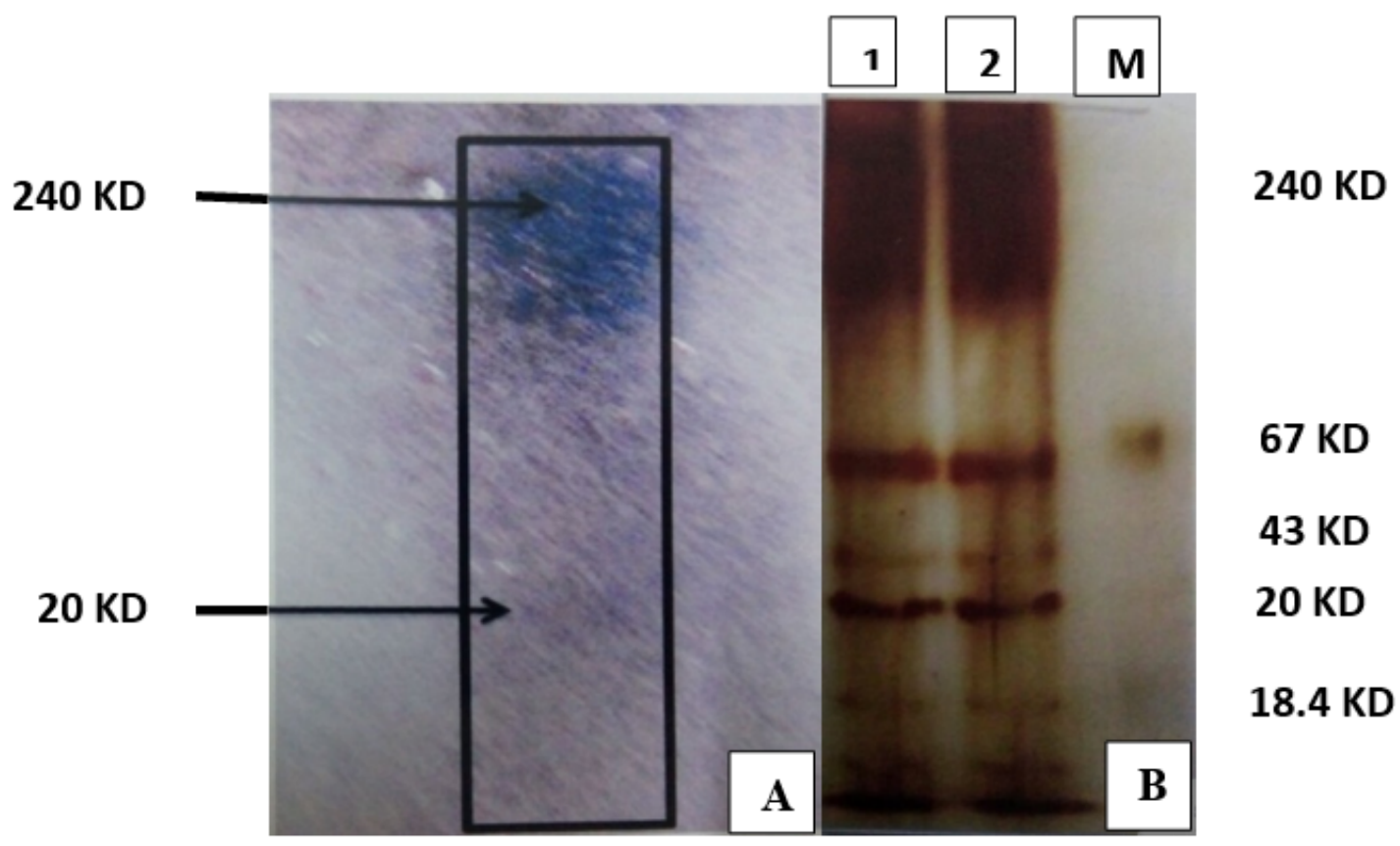

\section{Figure 11}

$12 \%$ Native Page and zymogram analysis (agarose gel containing $0.1 \%$ Colloidal Chitin) of crude chitinase from culture filtrate of active isolate Streptomyces ANU5a. (A) Arrow indicates the size of crude enzyme (B) Lane $1 \& 2$ are the duplicates for enzyme and $(M)$ is the broad range marker. 